\title{
CLINICAL AND HAEMATOLOGICAL PARAMETERS IN LACTATING COWS UNDER THE INFLUENCE OF HIGH AIR TEMPERATURE AND VOLUNTARY AND FORCED MILKING
}

M. O. ZAKHARENKO, Doctor of Biological Sciences, Professor

Department of Veterinary Hygiene named after Professor A. K. Skorokhodko https://orcid.org/000-0002-3179-6940

E-mail: sangin1996@ukr.net

A. Yu. MOLODKOVETS, Graduate Student

Department of Veterinary Hygiene named after Professor A. K. Skorokhodko https://orcid.org/0000-0002-2760-6876

National University of Life and Environmental Science of Ukraine, Kyiv, Ukraine

E-mail: a.molodkovets@nubip.edu.ua

\begin{abstract}
The effect of high air temperature on clinical and hematological parameters in lactating cows during voluntary and forced milking when they are kept in frame cowsheds made of steel structures was studied. During forced (milking parlor) and voluntary (milking robot) milking the heart rate of cows increased by 5 and 15 beats per minute, respectively, and the number of respiratory movements increased from 50 to 77 at high air temperature in the cowshed that is 1.7 and 2.1 times higher than at optimal values of this microclimate indicator. It was identified that the body surface temperature of cows depended on the air temperature in the cowshed during forced milking and, at high air temperature, it increased to $35.8-37.9^{\circ} \mathrm{C}$, which was 6.9 $7.5{ }^{\circ} \mathrm{C}$ above its optimal value, while this indicator of the udder increased from 31.6$33.3{ }^{\circ} \mathrm{C}$ up to $32.3-38.5{ }^{\circ} \mathrm{C}$. Humidification and irrigation of body surface in lactating cows in combination with increasing the airspeed to $1.2 \mathrm{~m} / \mathrm{s}$ in the storage reduced body surface temperature of lactating cows to $33.2-34.5^{\circ} \mathrm{C}$ that an average turned out to be by $2.5-4.7^{\circ} \mathrm{C}$ lower than similar indicators for animals in the cowshed. The hemoglobin concentration in the blood of lactating cows is lower by $15.6 \mathrm{~g} / \mathrm{L}$, the number of band neutrophils - by 3.9\% and monocytes - by $2.6 \%$ under high air temperature compared with the optimal. During voluntary milking at high temperatures compared with the optimal, the hemoglobin content in the blood was lower by $47.2 \mathrm{~g} / \mathrm{L}$, the number of white blood cells - by $1.95 \mathrm{~g} / \mathrm{L}$, and monocytes - by $6.25 \%$.
\end{abstract}

Keywords: lactating cows, milking parlor, milking robot, forced and voluntary milking, air temperature, clinical and hematological parameters 


\section{Introduction}

High-yielding cows differ from low-yielding animals by the high metabolic intensity in tissues and the ability to transform nutrients into milk components more efficiently (Chagas et al., 2007). As a result, most animal organs and systems, functioning at the limit of their capabilities, undergo a physiologic abnormality in the body, especially the ability to reproduce. Hot ambient conditions and low humidity in the cowsheds are critical for high-yielding lactating cows in summertime (Chomayev \& Mityashova, 2009).

\section{Analysis of recent researches and publications}

According to research (Martynova, 2012), hot ambient conditions in the cowshed reduce the average daily milk production, and the cow lactation performance is not restored to its previous level. Under such conditions, the number of non-yielding cattle reaches $27-30 \%$ of the total number of high-yielding cows, and the average term of their productivity is reduced to an average of 2.3-2.7 lactations (Mishchenko, 2008). Intensive use of cows under conditions of constant exposure to stress factors on the body, including hot ambient conditions (Taranov, 1983; Andreev et al., 2012), adversely affects animal health, changes hematological parameters and metabolic state in the body (Sheyenkina et al., 2013). Thus, according to Koryakina (2010), in summer, the hemoglobin concentration in the blood of cows increases by $16.8-27.0 \%$, the red blood cell count increases by $13.0-34.0 \%$ and the white blood cell count increases up to $10.2 \times 10^{9} / \mathrm{L}$. The eosinophil count in the blood of cows increases by $2.94 \%$ in summer and the monocytes count increases by $29.42-32.5 \%$ compared to these figures in spring (Mukhamed'yarova, 2014). The thermoneutral temperature limits for lactating cows have been established, the value of their critical points is from -5 to $20^{\circ} \mathrm{C}$, and the comfort zone corresponds to the air temperature of $5-10^{\circ} \mathrm{C}$. In hot ambient stressful conditions, the feed consumption and milk yield decrease in lactating cows, lung ventilation increases, and the physical and chemical thermoregulation processes are compromised (Dibirov, 2013). Under the stress conditions induced by prolonged hot ambient temperature, lactating cows change their behavior, the animals spend most of the time standing in the cubicles, less resting lying down, these factors cause "high-stress" tendon and claudication (Petrusha \& Dibirov, 2014). Under stress induced by hot ambient conditions, the lactating cows' reproductive function compromises, endometrium disfunction appears, embryonic mortality increases because of changes in the follicular ceruminous maturation and the hormone concentrations in the blood. Recently, a voluntary method for cow milking using modern milking robots has been introduced into the practice of dairy cattle operations. However, studies of clinical and hematological parameters in high-yielding lactating cows under stress induced by hot ambient conditions and milking using milking robots when they are kept in frame-type cowsheds made of steel structures are still out of consideration.

Purpose is to study clinical and hematological parameters in lactating cows under hot ambient stressful conditions in the cowshed in the terms of forced and voluntary milking.

\section{Materials and methods of research}

The experiment has been conducted in institution "Terezine" PLC, Bila Tserkva district of Kyiv oblast. For the 
experiment, 2 groups of lactating cows of holsteinized black-spotted breed of the $2^{\text {nd }}-3^{\text {rd }}$ lactation with lactation performance of 8000-8500 kg of milk per lactation, 8 heads in each, were formed. Cows of the first experimental group were kept in the frame-type cowshed cubicles, designed for 400 heads and 100 animals were kept in each technological (production) group. The animals were fed from the feeding table with a high-energy feed mixture. The animals had free access to food and water during the day. Cows were milked three times a day in a milking parlor (forcibly), equipped with a De-Laval installation (parallel) designed for simultaneous milking of 32 cows.

The second experimental group of lactating cows in the amount of 8 heads was also formed from animal analogs, which were kept in the cubicle of another cowshed designed for 500 heads, 125 heads in the technological (production) group. The cows of the second experimental group were milked voluntarily using a milking robot (De-Laval). The animals were fed with a feed mixture from the feeding table and provided free access to feed and water during the day. The type of diet and diet density for cows during voluntary milking were the same as for the forced milking but with free-stall housing and the ability to rest in cubicles. Animal waste from the second cowshed was removed using a delta scraper. Lactating cows selected for the research were clinically healthy, and their average daily milk production averaged 26.2$28.0 \mathrm{~kg}$. In the course of the experiment, clinical and hematological parameters were monitored in cows of the experimental groups, taking into account the method of milking - forced (milking parlor) and voluntary (milking robot) under optimal $\left(10-18^{\circ} \mathrm{C}\right)$ and hot $\left(25-29^{\circ} \mathrm{C}\right)$ ambient conditions in the cowsheds.
These clinical parameters in cows of the first experimental group were determined when they were both in the cowshed and in the storage (in front of the milking parlor), and cows of the second experimental group were in the cowshed, controlling body temperature, pulse, respiratory rate, udder and body surface temperature (torso) in the dynamics at 6:00, 9:00, 12:00, 15:00, 18:00 o'clock for two days in the period of optimal (April) and critically hot ambient conditions (July) (Tsvilikhovskyi et al., 2014). Blood samples in the experimental cows were taken from the coccygeal vein before morning feeding, which were used to determine the blood morphological composition, namely the red blood cell count and white blood cell count as well as the ratio of eosinophils, band forms and segmented neutrophils, monocytes, and lymphocytes. Erythrocyte sedimentation rate (ESR), hemoglobin content, and leukocyte analysis were also examined in animal blood (Karpishchenko, 2002).

The research results were processed statistically using Microsoft Excel software.

\section{Results of the research and their discussion}

Experiments have shown that during forced and voluntary milking, the rectal body temperature of lactating cows corresponded to the physiologically normal state established for animal species and the clinical state of animals. In hot ambient conditions in the cowshed, this indicator in lactating cows did not differ from its values under optimal air temperature during both voluntary and forced milking (Table 1). It should be noted that the difference in the pulse beat number and the respiratory movement frequency during forced (milking parlor) and volun- 
tary (milking robot) milking hasn't been established. However, the heart rate in lactating cows has increased by 5 beats per minute during forced milking and hot ambient conditions in the cowshed compared to the optimal one, and at the same time, the respiratory movement number has increased to 50, which turned out to be 20 beats more. In such hot ambient conditions in the cowshed and voluntary milking of cows by a milking robot, the pulse rate in experimental animals has also turned out to be 15 beats per minute higher, and the respiratory movement number has increased to 65 , which turned out to be 42 beats higher than similar figures at optimal air temperature. In hot ambient conditions, the number of respiratory movements in lactating cows during voluntary milking has turned out to be 15 higher compared to forced milking in the milking parlor. Thus, forced and voluntary milking had almost no effect on the clinical condition parameters in time of optimal air temperatures, which corresponded to their statutory figures (Tsvilikhovskyi et al., 2014).

Significant clinical changes in the lactating cows under hot ambient stressful conditions have been determined. It has turned out that the respiratory movement number in lactating cows under hot ambient conditions in the cowshed compared to the optimal temperature in the terms of forced milking (milking parlor) has increased in the morning at $6: 00$ by 20 , at $9: 00$ by 28 , at $12: 00$ by 29 , at $15: 00$ by 41 , at $18: 00$ by 35 respiratory movements per minute (Table 2 ).

In the course of the experiment, this figure in lactating cows during forced milking under hot ambient conditions on average has increased by 1.7 times compared to its optimal value. During the day, the udder temperature in lactating cows during forced milking under hot ambient stressful conditions has also become significantly higher than in animals under optimal air temperatures, e.g., at $6: 00$ by $5.0{ }^{\circ} \mathrm{C}$ higher, at 9:00 by $4.80{ }^{\circ} \mathrm{C}$ higher, at $15: 00$ by $4.68{ }^{\circ} \mathrm{C}$ higher, at $18: 00$ by $3.20{ }^{\circ} \mathrm{C}$ higher. In lactating cows under hot ambient conditions in the cowshed, the body surface temperature has increased compared to its values under optimal air temperature. Thus, in the morning at 6:00 o'clock, this figure in animals turned out to be $6.30{ }^{\circ} \mathrm{C}$ higher, at 9:00 by $7.6{ }^{\circ} \mathrm{C}$ higher, at $12: 00$ by $6.89^{\circ} \mathrm{C}$ higher, at $15: 00$ by $6.75^{\circ} \mathrm{C}$ higher, at $18: 00$ by $5.55^{\circ} \mathrm{C}$ higher. Hot ambient conditions in the cowshed have also significantly affected the body surface temperature in lac-

\section{Indicators of the clinical condition in lactating cows under optimal and high air temperature during forced and voluntary milking $(\mathrm{M} \pm \mathrm{m})$}

\begin{tabular}{|l|c|c|c|c|}
\hline \multirow{2}{*}{\multicolumn{1}{|c|}{ Indicator }} & \multicolumn{2}{|c|}{ High air temperature } & \multicolumn{2}{c|}{ Optimal air temperature } \\
\cline { 2 - 5 } & \multicolumn{2}{|c|}{ milking cows } & \multicolumn{2}{c|}{ milking cows } \\
\cline { 2 - 5 } & forced & voluntary & forced & voluntary \\
\hline Body temperature, ${ }^{\circ} \mathrm{C}$ & $39.12 \pm 0.37$ & $39.0 \pm 0.30$ & $38.34 \pm 0.26$ & $38.07 \pm 0.16$ \\
\hline Puls, beats/min & $77.0 \pm 2.0 *$ & $78.0 \pm 5.0 *$ & $72.0 \pm 1.0$ & $63.0 \pm 3.0$ \\
\hline $\begin{array}{l}\text { Number of respiratory } \\
\text { movemens/min }\end{array}$ & $50.0 \pm 6.0 * *$ & $65.0 \pm 15.0 * *$ & $30.0 \pm 6.0$ & $23.0 \pm 3.0$ \\
\hline
\end{tabular}

Note: * a significant difference $(\mathrm{P}<0.05)$ between indicators in cows during forced and voluntary milking; ** under the exposure to optimal and high air temperature. 
tating cows, which were moved to the milking parlor before milking. In hot ambient conditions, this lactating cows' factor almost did not differ from similar figures in animals at optimal air temperature, but it has turned out to be on average $2-3{ }^{\circ} \mathrm{C}$ higher in both the first and second cases than its figure in animals in the cowshed. A significant reduction in the body temperature of cows in the storage can be achieved by irrigating the animal body surface, humidifying the air with water, and increasing airspeed. Air humidification and irrigation of the body surface in lactating cows in combination with increasing airspeed to $1.2 \mathrm{~m} / \mathrm{s}$ in the storage have reduced the body surface temperature of lactating cows to $33.2-34.5^{\circ} \mathrm{C}$, which has turned out to be on average 2.5 $4.7^{\circ} \mathrm{C}$ lower than similar figures in animals that were in the cowshed.
Thus, experiments have shown that the surface temperature of the body and udder, as well as the number of respiratory movements in lactating cows significantly depend on the air temperature in the cowshed, and the latter on the outside air, which often goes beyond the thermoneutral zone in summer $\left(5-10^{\circ} \mathrm{C}\right)$. The most significant hygienic effect on the clinical parameters of lactating cows was registered at 15:00 o'clock, when the air temperature in the cowshed reached its maximum and was $28-32{ }^{\circ} \mathrm{C}$. Under such factor's figures, the body surface temperature in lactating cows increases to $35.8-37.9^{\circ} \mathrm{C}$, which reduces the process of heat transfer to the environment, and leads to heat stress in animals.

The cowshed's air temperature has significantly affected the hematological parameters in lactating cows, despite the fact that during forced milking the num-

\section{Indicators of the clinical condition in lactating cows under optimal and high air temperature (forced milking) $(\mathbf{M} \pm \mathbf{m}, \mathbf{n}=\mathbf{8})$}

\begin{tabular}{|c|c|c|c|c|c|}
\hline \multirow{2}{*}{$\begin{array}{c}\text { Air tem- } \\
\text { perature } \\
\text { in the } \\
\text { cowshed }\end{array}$} & \multirow{2}{*}{ Time of day } & $\begin{array}{c}\text { Number of } \\
\text { respiratory } \\
\text { movements/ } \\
\text { min }\end{array}$ & $\begin{array}{c}\text { Udder tem- } \\
\text { perature, }{ }^{\circ} \mathrm{C}\end{array}$ & $\begin{array}{c}\text { Body surface } \\
\text { temperature } \\
\text { of cows, }{ }^{\circ} \mathrm{C} \\
\text { (cowshed) }\end{array}$ & $\begin{array}{c}\text { Body surface } \\
\text { temperature } \\
\text { of cows, } \\
\text { (storage) }\end{array}$ \\
\hline \multirow{4}{*}{ High } & $6: 00$ & $50.0 \pm 9.0^{*}$ & $37.33 \pm 1.30^{*}$ & $35.80 \pm 0.98^{*}$ & $34.52 \pm 1.86$ \\
\cline { 2 - 6 } & $9: 00$ & $59.0 \pm 9.0^{*}$ & $36.62 \pm 0.74^{*}$ & $36.60 \pm 0.47^{*}$ & \\
\cline { 2 - 6 } & $12: 00$ & $61.0 \pm 13.0^{*}$ & $32.27 \pm 0.81$ & $37.94 \pm 0.81^{*}$ & $33.24 \pm 1.21$ \\
\cline { 2 - 6 } & $15: 00$ & $77.0 \pm 5.0^{*}$ & $37.81 \pm 0.88^{*}$ & $37.68 \pm 0.82^{*}$ & \\
\cline { 2 - 6 } & $18: 00$ & $67.0 \pm 12.0^{*}$ & $38.53 \pm 0.78^{*}$ & $37.01 \pm 0.88^{*}$ & $34.48 \pm 0.72$ \\
\hline & The average & $63.0 \pm 7.0 *$ & $36.51 \pm 1.69$ & $37.00 \pm 0.64^{*}$ & $34.08 \pm 0.56$ \\
\cline { 2 - 6 } & $6: 00$ & $30.0 \pm 5.0$ & $32.33 \pm 1.07$ & $29.48 \pm 1.88$ & $32.13 \pm 0.85$ \\
\cline { 2 - 6 } & $9: 00$ & $31.0 \pm 7.0$ & $31.75 \pm 1.62$ & $28.94 \pm 2.72$ & \\
\cline { 2 - 6 } & $12: 00$ & $32.0 \pm 6.0$ & $31.63 \pm 1.30$ & $31.05 \pm 1.32$ & $31.95 \pm 1.24$ \\
\cline { 2 - 6 } & $15: 00$ & $36.0 \pm 6.0$ & $33.13 \pm 0.88$ & $30.93 \pm 0.76$ & \\
\cline { 2 - 6 } & $18: 00$ & $31.0 \pm 6.0$ & $33.29 \pm 0.76$ & $31.46 \pm 1.06$ & $33.20 \pm 0.67$ \\
\cline { 2 - 6 } & The average & $32.0 \pm 2.0$ & $32.42 \pm 0.62$ & $30.37 \pm 0.92$ & $32.42 \pm 0.51$ \\
\hline
\end{tabular}

Note: * a significant difference $(\mathrm{P}<0.05)$ between indicators under high air temperature compared to optimal. 
ber of red blood cell count in the blood of animals under hot ambient conditions did not change compared to optimal air temperature and corresponded to the physiologically normal state (Table 3 ).

It has been found that the hemoglobin concentration in the blood of lactating cows during forced milking under hot ambient conditions in the cowshed was within the physiologically normal state and did not differ from its content in animals under optimal air temperature. The number of red blood cell count in the blood of lactating cows during voluntary and forced milking under hot ambient conditions, compared with the optimal temperature also did not change (Table 3 ). In addition, in the blood of lactating cows during both forced and voluntary milking under hot ambient conditions in the cowshed, no changes have been found in the total white blood cell count compared to optimal air temperature, this indicates no temperature effect on the functional status of hematopoietic glands.

However, control of the different white blood cell count ratio in the blood of lactating cows with different milking methods has shown that hot ambient conditions had an effect on some subpopulations of white blood cells. Thus, the eosinophil count in the blood of lactating cows under different methods of milking in hot ambient conditions has not changed compared to optimal air temperature. In the lactating cows under hot ambient conditions in the cowshed both during forced and voluntary milking, a small basophil count has been detected in the blood, while under optimal factors, these cells have not been detected (Table 3). In lactating cows under hot ambient conditions and voluntary milking, the band neutrophils have turned out to be 2.3 times higher, and in the case of forced milking, on the contrary, it has become 1.9 times lower than the figure under optimal air temperature. The experiment has also shown differences in the band neutrophils count in the blood of cows under optimal air temperature, which turned out to be 3.4 times less for voluntary milking than for forced one. However, no differences regarding this indicator have not been found in lactating cows during forced and voluntary milking under high temperatures in the cowshed. It has been found that under the optimal air conditions in the cowshed in the blood of lactating cows during voluntary milking, the segmented neutrophils count is 1.7 times higher compared to the forced milking, while at high temperature the difference in this parameter has not been established. There has been a significant decrease in the absolute monocyte count in the blood of cows under hot ambient conditions in both forced (7.9 times) and voluntary milking (9.3 times), compared with its content in animals at the optimal temperature (Table 3). In hot ambient conditions in the cowshed, the lymphocytes count in the blood of cows during voluntary milking compared to the optimal temperature has turned out to be $32.7 \%$ higher, and during forced milking has not changed at all. Hot ambient conditions in the cowshed reduced blood ESR in lactating cows during voluntary milking by 5.7 times compared to its figure at optimal temperature. There have also been revealed certain differences in blood ESR in lactating cows during voluntary and forced milking both under optimal and hot ambient conditions. Thus, at the optimal temperature, the blood ESR in lactating cows during voluntary milking has been 4.2 times higher, and in hot ambient conditions it has turned out to be 2.0 times higher compared to forced milking (Table 3 ). The revealed changes in the blood morphological com- 


\section{Influence of high air temperature on hematological parameters in lactating cows during voluntary and forced milking $(\mathbf{M} \pm \mathbf{m}, \mathbf{n}=\mathbf{8})$}

\begin{tabular}{|l|c|c|c|c|}
\hline \multirow{2}{*}{\multicolumn{1}{|c|}{ Parameter }} & \multicolumn{2}{|c|}{ High air temperature } & \multicolumn{2}{c|}{ Optimal air temperature } \\
\cline { 2 - 5 } & $\begin{array}{c}\text { forced } \\
\text { milking }\end{array}$ & $\begin{array}{c}\text { voluntary } \\
\text { milking }\end{array}$ & $\begin{array}{c}\text { forced } \\
\text { milking }\end{array}$ & $\begin{array}{c}\text { voluntary } \\
\text { milking }\end{array}$ \\
\hline Red blood cells, 1012/L & $5.50 \pm 0.94$ & $5.08 \pm 0.69$ & $6.61 \pm 0.39$ & $6.50 \pm 0.50$ \\
\hline Hemoglobin, g/L & $95.19 \pm 9.31^{* *}$ & $79.38 \pm 9.38^{* *}$ & $110.85 \pm 4.44$ & $126.62 \pm 7.87$ \\
\hline White blood cells, 109/L & $5.38 \pm 1.10$ & $5.17 \pm 0.90^{* *}$ & $7.12 \pm 0.93$ & $7.12 \pm 2.15$ \\
\hline Eosinophils, \% & $0.88 \pm 0.66$ & $2.0 \pm 1.50$ & $2.28 \pm 1.55$ & $1.87 \pm 1.12$ \\
\hline Basophils, \% & $0.75 \pm 0.56$ & $0.25 \pm 0.38$ & 0 & 0 \\
\hline Band neutrophils, \% & $4.50 \pm 1.62^{* *}$ & $5.88 \pm 2.59$ & $8.42 \pm 2.65$ & $2.50 \pm 1.50^{*}$ \\
\hline Segmented neutrophils, \% & $29.50 \pm 8.75$ & $23.25 \pm 4.06$ & $30.42 \pm 4.08$ & $52.25 \pm 8.37 *$ \\
\hline Lymphocytes, \% & $63.63 \pm 6.13$ & $69.13 \pm 3.38$ & $55.71 \pm 5.38$ & $36.37 \pm 7.78^{*}$ \\
\hline Monocytes, \% & $0.38 \pm 0.47 * *$ & $0.75 \pm 0.56^{* *}$ & $3.00 \pm 1.71$ & $7.00 \pm 1.75^{*}$ \\
\hline ESR, mm & $1.25 \pm 0.25$ & $0.63 \pm 0.28$ & $0.85 \pm 0.30$ & $3.62 \pm 1.28^{*}$ \\
\hline
\end{tabular}

Note: * a significant difference between the indicators during forced and voluntary milking of cows, ${ }^{* *}$ under high and optimal air temperature.

position parameters of lactating cows, which were kept in a cowshed under hot ambient conditions, are probably the consequences of a decrease in the feed consumption by animals and the motor activity reduction. The influence of hot ambient conditions on the hematopoietic glands' functional state by changing the intensity of redox processes in tissues has not been excluded.

Thus, based on the research, it can be concluded that hot ambient conditions in the cowshed, not only change the clinical state in lactating cows, but also the blood morphological composition to a much greater extent than during forced or voluntary milking of animals.

\section{Conclusions and future perspectives}

Experiments have shown that hot ambient conditions increase the number of respiratory movements and heart rate in lactating cows at constant animal body temperature compared to optimal air temperature. In hot ambient conditions in the cowshed, the udder and body surface temperature of cows increases, and humidification and irrigation of the animal body surface with water in the storage reduces the body surface temperature by 2.6-4. ${ }^{\circ} \mathrm{C}$. In the blood of lactating cows under hot ambient conditions and voluntary milking, the hemoglobin concentration, absolute basophil count, absolute monocyte count, segmented neutrophil count, and erythrocyte sedimentation rate decreases, but the band neutrophil count and absolute lymphocyte count increases compared with optimal air temperature.

The blood morphological composition changes in lactating cows under hot ambient conditions and forced milking that is confirmed by an increase in absolute basophil count and erythrocyte sedimentation rate, in parallel with a decrease in the band neutrophil count as well as absolute monocyte count at constant figures of other parameters.

Prospects for further research may be the thermoregulation phenomenology in lactating cows in hot ambient conditions. 


\section{References}

Andreyev, A. I., Chikunova, V. I., \& Gur'yanov, A. I. (2012). Pokazateli krovi doynykh korov pri ispol'zovanii v ratsionakh raznykh vidov silosa [Blood indicators of dairy cows when used in diets different types of silage]. Agrarnaya nauka Evro-Severo-Vostoka, 4, 42-45.

Chagas, L. M., Bass, J. J., \& Blache, D. (2007). Invited review: New perspectives on the roles of nutrition and metabolic priorities in the subfertility of high-producing dairy cows. Journal of Dairy Science, 90(9), 4022-4032.

Chomayev, A. M. (2009). Vliyaniye razlichnikh faktorov na vosproizvoditel'nuyu funktsiyu produktivnykh korov [The influence of various factors on reproductive the function of high-yielding dairy cows]. Zootekhniya, 5, 27-29.

Karpishchenko, A. I. (2002). Meditsinskiye laboratornyye tekhnologii [Medical laboratory technology]. Sankt-Peterburg: Intermedika, 1, 269-296.

Koryakina, L. P. (2010). Vplyv umov seredovyshcha i sezonu roku na morfolohichni pokaznyky krovi velykoyi rohatoyi khudoby symental's'koyi porody [The influence of environmental conditions and the season of the year on the morphological parameters of the blood of Simmental cattle]. Yakuts'ka derzhavna sil's'kohospodars'ka akademiya, 1, 135.

Martynova, E. N., \& Yastrebova, E. A. (2012). Analiz mikroklimata zhivotnovodcheskikh pomeshcheniy v ekstremal'nykh pogodnykh usloviyakh [analysis of the microclimate of livestock facilities in extreme weather conditions]. Izhevskaya GSKHA, 3, 163.

Mukhamed'yarova, L. G. (2014). Sezonnyye osobennosti funktsionirovaniya organizma importirovannykh korov na kletochnom urovne [Seasonal features of the functioning of the body of imported cows at the cellular level]. Vestnik soveta molodykh uchënykh i spetsialistov chelyabinskoy oblasti, 2, 41.

Mishchenko, V. A. (2008). Analiz prichin zabolevaniy vysokoproduktivnykh korov [Analysis of the causes of the disease in highly productive cows]. GAU, 2, 20-24.

Sheyenkina, T. M., Stetsenko, I. I., \& Lyubin, N. A. (2013). Osobennosti vozrastnykh izmeneniy mineral'nogo profilya krovi pod vozdeystviyem razlichnykh dobavok [features of age-related changes in the mineral profile of blood under the influence of various additives]. Vestnik Ul'yanovskoy gosudarstvennoy sel'skokhozyaystvennoy akademii, 39 (23), 72-79.

Taranov, M. T. (1983). Izucheniye sdvigov obmena veshchestv u zhivotnykh [study of metabolic shifts in animals]. Zhivotnovodstvo, 9, 49-50.

Tsvilikhovskyi, M. I., Bereza, V. I., \& Sichkar, V. S. (2014). Vnutrishni nezarazni khvorobytvaryn [Internal non-communicable animal diseases]. Ahrarna osvita, 35, 42, 59, 60, 74.

Petrusha, Ye. Z., \& Dibirov, R. M. (2014). Produktyvnist i povedinka koriv za ekstremalnykh parametriv atmosfernoho povitria [Breedproductivity and behavior for extremal atmospheric air parameters]. Bila Tserkva: Bilotserkivskyi natsionalnyi ahrarnyi universytet.

Dibirov, R. M. (2013). Vplyv osnovnykh klimatychnykh faktoriv na produktyvnist molochnykh koriv [Influence of majorclimatic factors on the performance of dairy cows]. Visnyk Sumskoho natsionalnoho ahrarnoho universytetu. Seriia: Tvarynnytstvo, (1), 32-35.

\section{М. О. Захаренко, О. Ю. Молодковець (2020). КЛІНІКО - ГЕМАТОЛОГІЧНІ ПО- КАЗНИКИ ЛАКТУЮЧИХ КОРІВ ЗА ДІЇ ВИСОКОЇ ТЕМПЕРАТУРИ ПОВІТРЯ ТА ДО- БРОВІЛЬНОГО І ПРИМУСОВОГО ДОїНнЯ. Ukrainian Journal of Veterinary Sciences, 11(4): 22-30, https://doi.org/10.31548/ujvs2020.04.003}


Анотація. Досліджено вплив високоїтемператури повітря на клінічні тагематологічні показникивлактуючихкорівпідчасдобровільного іпримусовогодоїннязаїхнього утримання в корівниках каркасного типу із металевих конструкцій. У корів за високої температури повітря в корівнику, порівнюючи з оптимальною, частота серцевих скорочень під час примусового (доїльний зал) і добровільного (доїльний робот) доїння зростала відповідно на 5 і 15 ударів за хвилину, а кількість дихальних рухів збільшувалась із 50 до 77, що в 1,7 і 2,1 раза вище, ніж за оптимальних значень цього показника мікроклімату. Встановлено, що температура поверхні тіла корів під час примусового доїння залежала від температури повітря в корівнику й за високих значень зростала до $35,8-37,9{ }^{\circ} \mathrm{C}$, що було вищим на 6,9$7,5^{\circ} \mathrm{C}$ від ії оптимальної величини, тоді, як цей показник молочної залози збільшувався з $31,6-33,3{ }^{\circ} \mathrm{C}$ до $32,3-38,5^{\circ} \mathrm{C}$. Зволоження повітря та зрошування поверхні тіла лактуючих корів у комплексі з підвищенням швидкості його руху до 1,2 м/с у накопичувачі знижувало температуру поверхні тіла лактуючих корів до $33,2-34,5{ }^{\circ} \mathrm{C}$, що виявилось у середньому на 2,5-4,7 ${ }^{\circ} \mathrm{C}$ нижче, ніж аналогічні показники у тварин, які знаходилися у корівнику. У лактуючих корів за дії високої температури повітря, порівнюючи з оптимальною, в крові нижча концентрація гемоглобіну на 15,6 г/л, кількість паличкоядерних нейтрофрілів - на 3,9\% і моноцитів - на 2,6\%. За високої температури повітря та добровільного доїння корів вміст гемоглобіну в крові виявився нижчим на 47,2 г/л, кількість лейкоцитів - на 1,95 г/л і моноцитів - на 6,25\%, порівнюючи з оптимальною.

Ключові слова: лактуючі корови, доїльний зал, доїльний робот, примусове й добровільне доїння, температура повітря, клінічні та гематологічні показники 